\title{
The Images of Women in Selected Contemporary Short Stories by Contemporary Filipino Women Writers
}

\author{
Hasmina Domato Sarip (iD \\ Associate Professor, English Department, College of Social Sciences and Humanities, Mindanao State University, Marawi City, \\ Philippines \\ $\triangle$ Corresponding Author: Hasmina Domato Sarip, E-mail: hannasaripfzds@gmail.com
}

\section{ARTICLE INFORMATION}

Received: December 18, 2020

Accepted: February 09, 2021

Volume: 3

Issue: 2

DOI: 10.32996/ijels.2021.3.2.12

\section{KEYWORDS}

Images, Women, Feminism, Contemporary, Short Stories

\section{ABSTRACT}

This inquiry sought to discover the images of women as portrayed in the contemporary short stories entitled "Fallout" by Maria L.M. Fres-Felix and "Language" by Sunantha Mendoza. Feminist Literary Criticism, specifically liberal, radical, Freudian, socio-cultural, stereotypical feminist perspective were employed to critically analyze the actions and feminist perspective of the female characters. The study attempted to meet the following objectives: 1 ) to describe the images of women as depicted by the authors in the stories; 2) to identify the dominant devices used in the stories; and, 3) to determine the feminist themes conveyed in the stories. Through examining and analyzing the short stories, different images of women were discovered. The close textual reading resulted in the researcher's coming up with the following findings: female characters are portrayed as involved, sophisticated, strong-minded, competitive, independent and unconventional. The dominant devices are symbols, juxtaposition, foreshadowing, imagery, idiom, metaphor, irony and figures of speech were effectively utilized in the stories to probe the images of women that are found in each story. Indeed, women will come a long way in facing the battle against patriarchal values.

\section{Introduction}

The struggle for women's right to vote which spanned for three decades which is the site for early feminism in the Philippines. From this struggle has started the awakening of women activists and organizations that raised the class question in feminism and affirmed the need to restructure society and restructure gender for to be a feminist would mean to take part in this struggle.

It has come a long way from the lineage of centuries-old revolutionary struggle to a recent feminist direction on women liberation, from the roots of Babaylans gifted with both psycho-spiritual healing and political counsel, the women revolutionaries and fighters who faced the full force of Spanish conquerors, and American and Japanese colonizers, to the women professionals and religious who joined to march at EDSA against the dictatorship of Marcos. The actuality of this existence means that Filipino women truly understand gender oppression, that they are after all a relevant race. Also, with the two female presidents, Corazon Aquino and Gloria Macapagal Arroyo, and the first woman Supreme Court Chief Justice Maria Lourdes Aranas Sereno, have reflected the effort of women to involve themselves equally with men in political governance and as well as in the society. With the ubiquitous phenomenon of the Filipina domestic and overseas contract workers, Filipino women had been receiving appreciation for becoming members of the labor force and become the "pillars of the society."

While it can be said that Filipino women have gained more leverage than their other Asian sisters in uplifting their status in the society, their fight against oppression and exploitation is far from won. They may have come a long way but they still have far to go.

K C AL-KINDI CENTER $\mathbf{R}$ FOR RESEARCH AND $\boldsymbol{R}$ D DEVELOPMENT Your gateway to world-class research

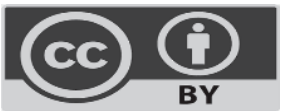

Published by Al-Kindi Center for Research and Development. Copyright (c) the author(s). This open access article is distributed under a Creative Commons Attribution (CC-BY) 4.0 license 
As shown in the report of Doctor Jose Ramon G. Albert during the national celebration of Women's month March of 2013, on politics, men have continued to keep a firm hold on electoral positions in both chambers. In the context or Philippine politics, women have traditionally not been the holders of power although some inroads have been made in the past decades. On labor and employment, there is the increasing participation of women in the labor force over the years. However, a wide gap between women and men still persists in the labor force participation rate. This could be due to gender biases as well as constraints in the household such as domestic responsibilities which itself is a gender issue. On judiciary, there is the rising share of female judges but still more share for men.

The majority Filipinas bear the brunt of oppression. As workers, farmers, migrant brides, and maids, as housewives and prostitutes, they are part of one people victimized by the patriarchal order; they are poor and powerless, they have the double day and their husbands, fathers, brothers, sons, union bosses, and political leaders seldom help or listen to them. Thus, a women's movement has arisen, waving the anti-imperialist, mass-oriented and feminist banner. In this movement, the personal merges with the political as human relationships forged in bed or within the larger home are clearly seen as extending to social sphere and inextricably connected to prevailing structures, ideas and institution in the society.

A breakthrough in the recognition of women's role in the public arena can be found in the Article II, Section 14 of the Philippine Constitution: "the state recognizes the role of women in nation-building, and shall ensure the fundamental equality before the law of women and men." But is this really observed in the other aspects like in the field of fiction and other literary pieces?

It has been the aim of the pioneering female writers to break the stereotypes and discrimination on how women are viewed in a patriarchal society. Through the use of their pen and words they have raised the feminist awareness of every reader. Aside from writing as a passion for art's sake these women have used it as a tool to gain literary recognition and to use literature and criticism to promote social change. And as literature offers complex realities of life as Filipino women lives it, it is this mirror that will be used for this reflective journey. This paper involves selected contemporary short stories as an attempt to explore the life of Filipino women as consciously or unconsciously presented by contemporary Female writers.

This paper, however, concerns itself with looking into the images of women - their attitudes, their roles, how they react in facing the challenges in life, and how they respond to what the society or the people around them dictate, as women writers project or shape them.

\section{Research Methodology}

The study began with the review of contemporary Filipino women writers and their works. The researcher searched for a book collection that would contain several short stories by Filipino women writers as subject for analysis and found the Likhaan Book of Poetry and Fiction 2000 suited very well for the study, a volume in the series of books intended by the Likhaan: U.P. Creative Writing Center to be a collection of stories and poems representative of the finest work being written out from thorough examination of fictions from journals, magazines and other periodicals produced by Filipino writers. The method used in selecting the stories was purposive sampling. The book contains eleven short stories by female writers the other stories included in the book were eliminated from the selection process because they were written by male writers. The researcher read and critically examined each story found in the collection. However, out of the eleven short stories written by female writers, only two were painstakingly chosen based on the gravity of its representations of women as embodied in the contemporary Philippine Literature.

When the short stories were finally chosen copies were secured, the application of the literary theory mentioned earlier which is Feminism followed. This study is an avenue for literary criticism involves analysis, interpretation and evaluation. The researcher read and analyzed the short stories focusing on women characters and their images. Furthermore, the researcher identified the literary elements and devices to reveal the relevance of these images as a literary piece and find out the feminist theme that took shape in each of the stories.

\section{Presentation, Analyses, and Interpretation of Texts}

This section gives the synopses of the short stories as well as the presentation, analyses, and interpretation of texts used in this study.

\section{FALLOUT}

Maria L.M. Fres-Felix 


\section{Synopsis}

The short story was set during the political uprising of martial law. Isi the narrator opened the story with the question why don't nuns suspend class and allow girls from their school join rally like the boys at the neighboring school do. She was a skinny $5^{\prime} 8$ girl who tried to do a flying kick on her P.E. class but ended up hitting her teacher's face instead of the piece of wood. Her mother, Emmy volunteered to be in the prom committee so Isi can join the debutante's circle. Her mother suggested that Alex David will be her date. Though Isi was protesting she cannot do anything but to obey her mother. Isi's mother got married right after graduation at 22. She had twin boys and then Isi at the age of 26 when martial law was declared

Isis's father, a stateside technocrat, worked in a government agency. He said he owes to serve the government after all it was the government who sent him on scholarship for his doctorate in the states. On the other hand, Isi's mother worked as a real estate broker. Though real estate faced crisis, she can still manage to attract buyers and sell properties.

Isi has attended the prom committee meeting, without her mother, along with the Phoebe Cates-Wannabees and their high maintenance mother. Right after they finish, she was fetched by Mang Hector. On their way home they were blocked at an intersection by a rally. Suddenly Isi saw her mother among the rallyist, wearing a hat and a shade for disguise. Isi was puzzled on what her father would say if he will learn about it.

Alex David came over to Isi's house. Isi's mother who was into healthy eating served him carrot cake. While Isi's mother was at the kitchen, Alex told Isi that his dad and other military guys are going to fix things up. Alex's and Isi's mother became friends when Isi's mother got herself elected to the Homeowner's Association to prevent their neighbors from their regular trash burning which caused Isi's asthma attacks.

After Alex had left, Isi asked her mother if her father knows that she was joining rally. Her mother said there was nothing she does that her husband does not know. Later on, did Isi noticed that her parents were acting so wooden unlike what they usually do. Until, after their family visit to the cemetery, Isi's parents were trying harder to act as if everything is fine. They were watching basketball when it was suddenly interrupted by an announcement of Marcos that he is calling for a snap election.

Meanwhile at the school, the thing about the prom preparations started to heat up too. The girls are into talking about gowns and stuffs and notes about their dates and who has the better wardrobe. Suddenly the girls ended up arguing about Imelda and Cory. When they asked Isi's opinion, she just said I don't know. At home her parents were also arguing about politics and the issue of involvement of Isi's mother in joining demonstrations.

A family friend went back to the Philippines from US upon learning about the snap election. Isi was asked by her mother to accompany Terence. Isi had a crush on him. Her mother got busy with the election campaign period supporting Cory who was the opposition candidate. Her brothers also joined the campaign, so she was usually left at home with her father.

Before the election Isi's mother went panic buying turning a spare bedroom into a minimart. On the news people are getting mauled and killed, so Isi's father had convinced her mother not to join the rally for the meantime. One Saturday night, Isi's father got angry, on TV screen was Marcos saying that the military was plotting to kill him. Her father came up to the realization that the government was already too much. Over the radio, Enrile and Ramos announced that they were breaking with Marcos and siding with Cory, likewise Isi's father has broken his psychological bond with the government he had served for so long.

After Sunday mass Isi's father suggested that maybe they could go to EDSA and join the revolution. Her mother was so happy and so they all went there. Isi concluded that there was goodwill and hope all around as the Marcoses fled and left Malacaňang palace. Isi's father and his colleagues tendered their courtesy resignation.

On the other hand, Isi's mother received a call from Mrs. David that she will not allow Alex to be Isi for she was a loyalist technocrat daughter. Her mother decided to fix her up with Terence as her date, but Terence was not available too for suddenly he got busy. At the end of the story Isi doesn't have a prom date so she may not be able to attend at all.

\section{What images about Filipino women are shown in the selected contemporary Philippine short stories by women writers?}

\section{A. A Working Mother}

Isi's mother, Emmy, is an epitome of a good housewife and a mother. Emmy got married right after she graduated at the age of 22. She had a twin and a daughter at 26 when martial law was declared. She is an affectionate loving mother. She manages her home very well. She is into healthy eating, substituting apple sauce for oil in her cooking, and gives her children crudités instead 
of potato chips. Held (1993) views women's unique experiences as mothers as the basis for new insights into power; as she puts it, "the capacity to give birth and to nurture and empower could be the basis for new and more humanly promising conceptions than the ones that now prevail of power, empowerment, and growth" (Allen, 2013).

A wife must confine herself to the domestic realm and must be knowledgeable and sensitive about the welfare of her family especially health of the children. It is the wife who is expected to be more concerned about the welfare of the children and must know how to be a good mother to her kids (Nakpil, 1963). This was portrayed by Emmy when she got herself elected to the Homeowner's Association to prevent their neighbors' regular trash burning which causes the asthma attacks of her daughter. She stayed at the association till the regulations on garbage disposal were implemented. Emmy was also a hands-on mother. She volunteered herself in her daughter's school prom committee so that Isi will be part of the debutante's circle. She even took charge of what to wear and who to date of her daughter.

Emmy too is an educated career-woman. She was a real estate broker selling condominiums and other related properties. Though real estate was in a slump at that time she still manages to get buyers and that was how her family managed to get by. She did not depend on his husband's income. She has broken the stereotype that women cannot participate in the economic sphere.

Luckily, Mama, the mangler of metaphors, can sell even Jones Bridge. That's how we managed to get by, even when the peso devalued 18 to a dollar. And Papa doesn't have to steal. (134)

\section{B. A Politically and Socially Involved Woman}

Emmy exhibits qualities of being involved and empowered. Patriarchy as a system oppresses women through its social, economic, and political institution. Throughout history men had greater power in both public and private sphere. Emmy outdid this stereotype; in the story she had twice demonstrated her strong conviction to change the society. First was when she got herself elected to the Home Owner's Association and another one was when she fearlessly joined rally demonstration to overthrow the Marcos administration.

For a deeper understanding that political, economic, and social issues are things outside women's lives: these are much within their condition as mothers, wives, lovers, sisters, daughters, or simply persons complete unto themselves (Kintanar, 1992). As a mother to be part of the Home Owner's Association was her way to prevent the asthma attacks of her daughter caused by the regular trash burning. Emmy joins the rally.

She must be relieving those demonstrations that she missed as a young mother. Or maybe, as a wife, she knows firsthand about the spiraling price of galunggong and all that, and is pretty much fed up. (136)

This is suggestive that issue outside the household domain has an impact to women's domestic roles, and that women's involvement on this issue should not be disregarded. It was Emmy's mother instinct that motivated her to participate in the activists group aiming to achieve changes in the country.

Moreover, Emmy is a woman who is confident and is not afraid to speak her mind. Which was obvious whenever she talks and debate to her husband. "Oh, my sweet Don Quixote, when will you wake up and smell serious money?" As a practical wife she can see that her husband can earn more money if he worked in a private sector. This illustrates that women have the same capacity as men for moral reasoning and agency.

"Remember because of corruption, our country is like these squatter families by the dumpsite - broke and breeding like rabbits. You yourself said that our great great grandchildren are mortgaged to foreign creditors. And for what? So they could live like kings?" (139)

The above statements by Emmy suggested that she is politically aware of what is happening in the country. She is strong minded and outspoken as well. She debunked the concept that women should only be kept at home and shun away from societal involvement

Mama is really into elections now that Cory is the opposition candidate. Maybe she sees herself as a crusading reformer too. She is campaigning like crazy, and Papa's words of caution can't penetrate her yellow fever craze. Maybe the president's remarks about women belonging to the bedroom have something to do with her zeal. (141) 
It can be noted that the call for full participation of women in the rights and duties of citizenship or right of woman suffrage in Marry Wollstonecraft's "A Vindication of the Rights of Woman" marked the first milestone of feminism for the equality of the sexes which was enjoyed by Filipino women after a hard campaign at a nationwide plebiscite in 1937. The story proved that women did not only enjoy the right of suffrage but also the right to hold position in politics. Women as represented by Cory Aquino succeeded in toppling the Marcos patriarchal dictatorship which proves that the Filipina is no simpleton fit only for the kitchen and the bedroom.

\section{A Sophisticated Woman}

The story has also portrayed the image of a sophisticated woman. This is a positive portrayal of woman as cultured, refined, and urbane. Isi's mother exhibits this in the story.

A yellow floppy hat I know belongs to my mom bobs along. I stare at the sun

flower crosstitch on the brim, the one I can pick out from a million others. (135)

She joined the rally wearing large beaming hat and shades for disguise. She makes skinny desserts such as crudités and putanesca with black olives. Despite the height of the demonstration, she was able to redecorate their old oak tree on Christmas. Her eagerness for her daughter to be part of the debutante's circle prom also shows her being a sophisticated person. This image can also be noticed with the girls at school, talking about gowns and comparing notes about their dates, as described:

Those Phoebe Cates-Wannabees, smelling of Nenuco are into heavy discussions with their high maintenance mothers...

Bianca, the ultimate deb, shows us her jeweled evening bag from Paris, saying her designer is making a matching gown. (135)

\section{A Strong-Minded Woman}

Isi, the narrator of the story displays a strong-minded image of a woman. This is sensed when she opened the story with her statement:

"PE is the pits, I mean, really why nuns don't suspend classes so we can join the rally like the boys in the neighboring school do? I bet carrying placards against Cronyism, Corruption and Poverty is more fun than this." (132)

The sentences suggest that Isi isn't adopting the traditional concept of women, she is eager to be involved into activities mostly dominated by boys. Her awareness of what cronyism, corruption and poverty suggests her being intelligent to figure out an independent thought about the political issues. She is a keen observer with an eye of a hawk taking notice of the happenings around her from home to school.

It can be seen that she is confined to the position of limited status of the traditional system. She was enrolled to an all-girl catholic school which was run by nuns. Even though she isn't interested with prom, she still has to do to obey of her mother's idea. She has her mother decide on what to wear and even who to date. She was fetched at school by her father's driver in a security plated beige lancer. She was raring to join rallies just like her mom but she cannot because her father will not permit her. Parental authority extends to the children's personal lives as well under the conviction that they know what is best for their children - because parents by have only their children's welfare at heart (Kintanar 1992). Moreover, this suggests the mechanism of construction of feminine gender of the character as social learning, the sum total of the parents', the peers', and the culture's notions of what is appropriate to each gender by way of temperament, character, interests, status, worth, gesture, and expression (Mikkola, 2012).

Isi's personal descriptions are fifteen years old, asthmatic, skinny, and 5' 8 " and started reading at three. Isi may be a girl but she has qualities equal to male, her height is above average among Filipino women. Her height is more likely average to male. Her being asthmatic and skinny limits her on reading and intellectual matters where she excels. She is outspoken and gives her opinion without reservation. Though she obeys her parents, she let them know what is on her mind.

\section{What literary elements and devices are used to reveal these images?}

The yellow ribbon is a constant motif in the short story. In a way it is a symbol for hope like the color of the sun, the one that one looks forward to in the morning especially when one has been staying in the dark for a long time. In the Philippine political history, the yellow color is very popular and symbolic. In fact, it had twice elected president in the country. First was Pres. Corazon Aquino during EDSA 1 and second is her son President Benigno Aquino III. The supporters of the Aquinos wore yellow during the EDSA revolution to oust the then administration of the Marcoses and it was again used as a motif for President Aquino's campaign for presidency, which he won. And when Cory Aquino died, the Filipinos again show their sympathy and loyalty to the ex-president, who is also considered as mother of the Filipino people by wearing yellow. 
The yellow color may be interpreted as weak but however based on the story and Philippine political history, yellow is a powerful color which unites the people of the Philippines in their desire to achieve political change when the country is suffering from corruption and poverty. Note that it was popularized by Cory Aquino, a woman, therefore the yellow fever craze is in some way a sign that women are taking participation in politics, that they too like men can be leaders.

The yellow ribbon in a way is a silent protest, a campaign to change the rampant and obvious corruption in the country. The yellow fever craze is infectious like a smile. A smile is a powerful tool to get what you want as the saying goes 'smile and the whole world will smile back at you.' In the same way, the yellow ribbon is also encouraging and infectious because for the Filipinos it stands for hope, a hope that somehow the country will finally be able to eradicate corruption and poverty.

Moreover, the preparation of the girls at school in their upcoming Juniors-Seniors prom is a foreshadowing of the EDSA revolution; while they were busy planning for haute couture, jewelries and shoes to use and possible dates for the prom, the Filipinos are also preparing and devising a plan for the EDSA revolution and it is implicitly presented in the story. Note that the girls at first compare gowns and all but at the later part they were talking about politics and the revolution and they have been divided into two factions: The Imeldas and the Coryist. The JS prom itself therefore stands for the revolution where the Filipinos are also divided into two: those who support the Aquinos and those who remain loyal to the Marcoses.

\section{What feminist themes are conveyed in the stories?}

The overall feminist theme presented in the story is that women are both socially and politically involved contradicting the remarks that women only belong to the bedroom as said by the president who was male "that women belonging to the bedroom have something to do with her zeal". This has been debunked by the female characters in the story that who participated in events and organization aiming for a reform in the country. Not only did women involve themselves in sociopolitical and economic issues in the country but she even became a leader of the country as in the case of Cory Aquino who was elected president. Above all these, women were portrayed as strong individual like male who can be equally powerful as men such that she can even support her family and be a leader and at the same time remain maternal and devoted to her family.

\section{Language \\ Sunantha Mendoza}

\section{Synopsis}

Joaquin told his wife, Patty, "You can't have your cake and eat it too." Patty was trying to figure out what does it mean. Maybe she thought it has something to do that she had gone back to college and her parents were the one paying for it.

Patty gave Joaquin a Shell Silverstein children's book on his twenty fourth birthday. She thought the book is a metaphor of what she feels. But Joaquin did not even bother to open the book.

Joaquin and Patty were seeing less each other. Joaquin went to work and Patty goes to school. Patty leaves her daughter Naomi who was three-year-old to her mother's house. One time, when Patty went home late with a bag of Kenny Rogers, she found Joaquin at the bathroom trying to let Naomi spit out the peppermint candle she took from Patty's mother's house. Joaquin dislikes the manner how Patty teach her daughter to be independent like letting her do things on her own. Joaquin and Patty resided at her father's apartment. His father let Joaquin pay for the sake of pride.

One night, Patty tried to start a conversation with Joaquin. He did not respond to her. He just slammed the closet door and went to bed. After half an hour he talked to Patty. He told her that he wished Patty will take better care of their daughter. They argued for a little while, then Joaquin took his car key and went out of the house. Patty picked up the book "The Missing Piece" and headed to Naomi's room. She woke accidentally woke her up so she read to her the book. She called her mother after and then the realization of the sudden nagging feeling of being a terrible wife and a terrible mother bothered her. Joaquin got back and Patty waited for him to say a word but he only sighed and turned the other way. Suddenly Patty was tempted to open her mouth and started singing.

\section{What images about Filipino women are shown in the selected contemporary Philippine short stories by women} writers?

\section{A. Unconventional Mother and Wife}

Patty is a young female character who and is just starting to live her life but because she got pregnant accidentally by her boyfriend, she was forced to marry young, quit school and take the role of both a mother and a wife of which she's both not 
ready. In the Philippine society it is a taboo to get pregnant out of wedlock so it is expected that if a woman gets pregnant whether she like it or not, the man has to marry her to cover the possible shame and humiliation it could bring to the family.

Patty is unconventional, modern and non-conformist. Despite the fact that Philippine society is conservative and traditional, her personality reveals that she is not what the society expects her to be. The fact that she conceived her baby in the car suggests that she isn't afraid to experiment and take risks even at a young age. As a result of her behavior, she got pregnant unexpectedly and has to marry the guy because of societal expectations that a woman shouldn't be carrying and raising a child alone otherwise she'll be the subject of talk and humiliation and people will start questioning her modesty and morality.

On the other hand, on the part of the male he isn't subject for such humiliation in fact, it can even add up to his machismo. This is one of the gender differences on the perspective of the feminists. Accordingly, cultural feminist looks to the different value associated with womanhood and femininity as a reason why men and women experience the social world differently. Other feminist theorists believe that the different roles assigned to women and men within the institutions better explain gender difference, including the sexual division of labor in the household. In addition to, Liberal feminists point out that marriage is a site of gender inequality and that women do not benefit from being married as men do. Thus, married women have higher levels of stress than unmarried women and married men (Ritzer and Goodman, 2004).

In the story, it can be noted that Patty's husband is constantly reminding her of her domestic role as a wife and a mother. He even tells her that she should be the one taking care of her daughter instead of other people referring to Patty's mother. He even developed a cold treatment towards her by speaking to her in idioms and sleeping with her became minimal. When Patty's father said that "the only good man is a dead man" with an exception of himself it means that the only good man is either dead or unborn but for Patty she thinks that she is good only if she doesn't exist when she said "The only good Patty is dead a Patty."

Patty is definitely not happy with her situation being a mother and a wife, she feels trapped and restricted. As a manifestation of that, she finds escapism and pleasure in watching music television. Even if her husband stopped doing bed business with her, she isn't affected, as she said

"watching MTV makes me think of sex. So I wonder if any of the Backstreet Boys are good in bed, especially since they keep baring their chests, and looking at the camera all serious-sexy-like which I know would make me laugh uncontrollably if someone tried to look at me that way in person." (221)

Patty can be noted in the story that she wants to free herself and have decision and a mind of her own. In the story, she has been told by her husband "You can't have your cake and eat it too." this is telling her that she can't have it all, that she has to compromise to her situation and is left without a choice but to accept her fate as a mother and wife because she is a woman. It is as good as saying her choice is to have no choice. In a patriarchal society, a woman is expected that her role is limited to household chores which feminist find a form of gender inequality. Accordingly, women have the same capacity as men for moral reasoning and agency, but that patriarchy, particularly the sexist patterning of the division of labor, has historically denied women opportunity to practice this reasoning. Women have been isolated to the private sphere and take care of household duties and child rearing.

Moreover, she isn't ready for her domestic role as a wife. She'd rather take-home food from fast food than cook or attend her class while leaving her child to the care of her mother. She even carelessly let her child go to bed without washing her up or fail to notice that some of her stuffed toys need washing. But her husband, on the other hand, noticed all these and considers them a negligence of Patty's duty as a wife.

Without turning to face me, he says, "I just wish you took better of care of Naomi."

I look up from my book. "Excuse me?"

"You're her mother, you should take care of her."

"What are you talking about? I do take care of her."

"You'd rather leave her with other people."

"My mother is not other people."

"She ate candle wax this afternoon for heaven's sake!"

I gently closed my book and explain, "Candle wax isn't toxic."

"Oh it isn't," says Joaquin, then suddenly gets up again and grabs a pair of jeans.

He pulls on his shoes shaking his head and muttering. "I don't believe this."

(223) 
In return, he developed a silent way of rebelling against her by treating her coldly and using idioms to communicate with her which is answered back by Patty through metaphor. Patty's husband Joaquin therefore is just like the society who expects that a woman's role is just limited to home, taking care of her husband and nurturing the children.

Patty indeed is not a maternal type of a woman because she doesn't feel like she wants to take care of another human being. It can be noted that when was only twelve years old she was fascinated with her dog Douglas but when she is face with the need to take care of him such as washing and feeding him, she left the dog to other people even if she really like it. In other words, she abhors the idea of taking responsibility of nurturing and caring. Even when her child was born, she didn't feel the maternal love as what most woman feel when they have babies instead, she feels that the baby is alien to her...

When Naomi and I came home from the hospital---before Joaquin and I were married and I was still living with my parents---I stayed up all night just staring at her in the crib, like I had kept staring at Douglas. You know how newborns don't have faces yet? I couldn't tell if she look like Joaquin or me. She seemed so alien. I didn't know what to do with her, I thought that mother's instinct thing was a whole bunch of crap. (224)

\section{What literary elements and devices are used to reveal these images?}

The story used allegory in the presentation of its theme and conflict. The first allegory is the story of The Missing Piece and next is the title Language. The Missing Piece is a children's book that Patty gave to her husband as gift to his birthday in a hope that it would send him a message on how she feels and what she thinks. Note that it is a children's book, which is inappropriate to give to an adult; but in a way by giving the book to her husband Patty assumes that she is sending a message to him. She ideates that she is the incomplete $O$ searching for its missing piece, something to complete her and when she finally finds it, she realized that she's not happy with it because she feels restricted and burdened.

The incomplete $\mathrm{O}$ is Patty herself and the missing piece that completed the letter $\mathrm{O}$ is her family, her husband and her daughter Naomi. But when she finally has them, she realized that she's burdened and restricted like the incomplete $O$ because she lost her freedom to do what she wants. She was forced to give up her studies when she got married and quit the band where she used to play the drum but when she had the chance to go back to school, she grabbed it even if she will have to sacrifice her time to her family. When she unexpectedly saw her old band mates playing in a gig, she felt frustrated and drink it off.

In addition to, the title is also an allegory to the plot of the story because language is a means to communicate but it can be noted that the husband and wife lacks clear communication that brought the conflict in the story. As defined in the MerriamWebster dictionary "language is a system of words or signs that people use to express thoughts and feelings to each other" but in the story the husband and wife communicate subtly and silently. The husband talks to the wife in idioms and the wife replies in metaphors. The silent treatment between the two of them and their mode of communication through gestures and metaphors reveals the difference of communication style between a man and a woman.

Moreover, idioms are also used in the story "you can't have your cake and eat it too," Joaquin said this to Patty at the beginning of the story. This was actually his manner of telling her to choose one between two things which she cannot have both. That is to go to school or to stay home and take care of their daughter Naomi. Another one was Patty's father's warning, "the only good man is a dead man," and Patty repeated "the only good Patty is a dead Patty".

\section{What feminist themes are conveyed in the stories?}

The theme of the story is represented by the story of The Missing Piece. Like the incomplete letter O, women also feel completer and more alive when she has the freedom to choose and decide for her life and not having others dictate and mandate her on what to do or how to act. Mackinnon claimed that it is a basic "fact of male supremacy" that "no woman escapes the meaning of being a woman within a gendered social system, and sex inequality is not only pervasive but may be universal (in the sense of never having not been in some form" (Allen, 2013).

In the story the protagonist is oppressed with the things she wants. Some say that a woman is incomplete without a husband or a man in her life but the story however tells that having a family isn't a guarantee for attaining happiness. A woman still craves for freedom and independence and that is her ultimate happiness. The concept that women should be confined to taking domestic role is a form of oppression and inequality because it limits her capacity as human being. And if she neglects to perform the duties imposed and defined by the society, she'll be accused as an irresponsible woman. 


\section{Conclusions and Recommendations}

This inquiry sought to discover the image of a woman as reflected in the selected contemporary short stories by contemporary Filipino women writers, the literary devices used to dramatize and illustrate these, and the feminist themes conveyed in the stories. The analysis done on the texts drew heavily of feminism, specifically liberal, radical, Freudian, socio-cultural, stereotypical feminist perspective for theoretical support and sustenance. Generally, feminist criticism sought to develop and uncover writings about female, interpret symbolism not on the male point of view, analyze them from a female perspective in order to resist sexism in literature and create awareness on the gender issues. Freudian or psychoanalytic feminist criticism was used in identifying and examining feminist issues or concerns in the stories, specifically the status of the Filipino woman as dramatized through the personalities, motives and experiences of the female characters in the story. Socio cultural feminism is used in probing the image and place of a woman as imposed by the society, culture and other environmental factors. Stereotypical feminist criticism is used in investigating feminist issues or concerns in the stories especially in identifying the biases. Some literary terms were borrowed from formalist approach or new criticism in the analysis for the literary devices used in the stories.

Fall Out is a story set during the martial law. "Isi," a fifteen-year-old, narrated the story from her point of view. The story tells say much about how the characters view the political uprising on hindsight and how revolution in the adult world rescues a teen aged-daughter from fate worse than death, or dictatorship - a bad prom date. As a daughter Isi is confined to obey her parent's authority. There are some things she wanted to do but she cannot, just like joining rally. And some things she does not want to do but she had to just like attending prom which was her mother's idea. Her mother is an epitome of a sophisticated hands-on working mother-wife who wanted what is best for her children and her family. Her mother, also, defies the patriarchal system's exclusion of women from social, political and economic activities. She is able to get involve in demonstrations and rally and as well in her domestic role as a wife and a mother. She is not afraid to speak up her mind to his husband. As a result, Isi somehow build up the character she observed from her mother. Isi displayed an image of a strong-minded minded and a good daughter as well.

In Language, Patty, a wife and a mother, get back to school 3 years after she gave birth to her daughter Naomi. She had to leave her daughter to her mother's house whenever she went to school and had to take home food from restaurants for their dinner whenever she came home late. For this reason, her husband developed a cold treatment towards her and even repressing her to her sexual needs. He wanted her to stay at home and be a good mother to their daughter. He asserts his male dominance and power that the patriarchal society has conferred on him through this and he expects her to obey on what he wants. Patty is a picture of an unconventional, non-conformist, and dependent woman. Though she was already married she was still dependent to her parent's support. At the end of the story, she had learned from her mother that the woman should learn to make compromises suddenly she felt a nagging feeling of being a terrible wife and a mother.

\section{References}

[1] Allen, A. (2013). Feminist Perspectives on Power, The Stanford Encyclopedia of Philosophy (Spring 2013 Edition). California. Stanford University.

[2] Butler, J. (1992). Feminist Theorize the Political. USA: Routledge Press.

[3] Eagleton, M. (1991). Feminist Literary Criticism. USA: Longman Inc. New York.

[4] Grosz, E. (1989). Sexual Subversions: Three French Feminists. Australia: Allen.

[5] Kaplan, C. (1986). Sea Changes: Culture and Feminism. London: Virago.

[6] Kintanar, T. (1992). Women Reading... (Feminist Perspective on Philippine Literary Texts). Quezon City: University of the Philippines Press.

[7] Mikkola, M. (2012). Feminist Perspectives on Sex and Gender, The Stanford Encyclopedia of Philosophy. California. Stanford University.

[8] Papadaki, E. (2012). Feminist Perspectives on Objectification, The Stanford Encyclopedia of Philosophy. California. Stanford University.

[9] Ritzer, G. and Goodman, D.J. (2004). Sociological Theory: Sixth Edition. Columbus, OH: McGraw Hill.

[10] Stevens, B. K. and Stewart, L. (1996). A Guide to Literary Criticism and Research. USA: Holt, Rinehart and Winston Inc.

[11] Woolf, V. (1929). A Room of One's Own. New York: Hancourt. 